\title{
Oiling the wheels? Flexible labour markets and the migration industry
}

David McCollum and Allan Findlay, Centre for Population Change, Geography and Geosciences, University of St Andrews

The growing commercialisation of migration, often through a multiplicity of labour market intermediaries, is an issue of increasing academic interest. We seek to contribute to an emerging research agenda on the migration industries by exploring how one of the key actors that constitutes it, recruitment agencies, sits at the nexus between flexible labour market structures and migrant labour. Interviews with UK labour providers and low-wage employers form the evidence base for an analysis of the strategies developed by recruiters to derive commercial gain from connecting the so-called 'supply' and 'demand' sides of the flexible international labour market. We seek to contribute to understandings of the analytical categories within migration systems by illustrating how the migration industry interacts with other key stakeholders to structure international migration.

Keywords: migration industries, migration systems, flexible labour markets, labour providers, East-Central European migration.

\section{Introduction}

In the 'age of migration' (Castles et al, 2013) an array of explanations have been formulated within the social sciences to try and explain the movement of people between places (Brettell and Hollifield, 2015). A common but often overlooked aspect of population mobility is that most international migrants draw on some form of intermediary to help them migrate to and find employment and/or accommodation in another country (Salt and Stein, 1997; McCollum et al, 2013; van den Broek et al, 2015). As noted by Lindquist et al (2012), the drivers behind individuals seeking to migrate, and what happens to them after they move are relatively well understood, but less is known about the 'black box' between these stages. Thus whilst the internal workings of intermediaries such as recruitment agencies, political and ethnic groupings and people smugglers have received some attention (Findlay, 1990; Findlay and Li, 1998; Soysal, 1994; Friebel and Guriev, 2006), understanding of their role in international migration remains underdeveloped in theoretical terms (Hernandez-Leon, 2013; Coe et al, 2010; Cranston, 2016). Building on research on migration intermediaries, the concept of the migration 'industry' has recently emerged to loosely encompass those individuals and organisations involved in enabling migration, such as money lenders, recruiters, transportation 
providers, travel agents, smugglers and lawyers, whose primary motive is profit (Sorensen and Gammeltoft-Hansen, 2013). The migration industry has thus been defined as 'the ensemble of entrepreneurs who, motivated by the pursuit of financial gain, provide a variety of services facilitating human mobility across international borders' (Hernandez-Leon, 2008, 154). With some exceptions (Garapich, 2008; Hennebry, 2008), this still evolving concept has usually been equated with systems designed to facilitate irregular and quasi-legal migration across international borders (Bilger et al, 2006; Kyle and Koslowski, 2001; Lindquist, 2010; Koser, 2011). In practice the migration industry is much more engaged in legal migration flows, yet this dimension of the industry remains somewhat neglected.

Using the empirical lens of the unprecedented inflows of labour migrants to the UK from EastCentral Europe over the period 2004-2010 (so-called 'A8' migrants), this research hopes to contribute to the developing research agenda on the migration industries through a focus on how the labour provider industry operates to meet the preferences and needs of low wage employers, and how in the process they are an important part of a migration system that produces 'flexible' workers for 'flexible' jobs. Specifically the analysis concentrates on the strategies used by recruiters to derive profit from the process of matching migrants seeking employment opportunities with employers seeking 'good' (migrant) workers.

\section{The migration industry: conceptual contributions}

This research has been spurred by a desire to engage with what Hernandez-Leon has described as 'the gaping theoretical hole concerning the position, contribution and relations of profitdriven actors in the social organisation of international migration' $(2013,24)$. Whilst it is certainly the case that much remains to be conceptualised concerning the 'black box' between individuals wishing to engage in mobility and their arrival in a new country (Lindquist et al, 2012), it would be foolhardy to take the view that the role of profit-orientated intermediaries in facilitating international migration is devoid of an evidence base. Migrants have long relied on others not only to help cross international borders but also to adjust to life after moving. This has been achieved not just as a result of transnationalism from below, in terms of migrants' links to transnational communities (Vertovec, 2009), but also as a result of transnational 
business connections and the structuring influence of corporate capital to engage external assistance to facilitate the mobility of expertise (Salt and Wood, 2011; Hedberg et al, 2014).

This in turn has resulted in a global migration industry that is concerned on the one hand with the technicalities associated with supporting international transfers and on the other hand with the very business of producing how migrants experience migration (Cranston, 2016). In the context of recent East-Central European labour migration to the UK, researchers with a particular interest in recruitment practices have shown how dynamic the migration industries have been not only in adapting to changing economic circumstances but also to tailoring their role relative to shifting cultural norms about 'the good migrant' (McDowell et al, 2008; Sporton, 2013; Findlay and McCollum, 2013; Pemberton and Stevens, 2010; Jones, 2014). Understandings of 'the good migrant' are central to discussions surrounding the migration industry, since they reflect prevalent normative understandings of what is understood to be the 'ideal' worker. These knowledge practices are of interest and importance because they shape recruitment and employment practices, and thus labour migration flows, by influencing who is recruited, from where and for what purposes (Findlay et al, 2013).

Whilst 'labour providers' (this term is used to indicate that international recruitment agencies and other profit-orientated individuals and organisations are engaged in much more than organising the spatial relocation of workers) have long been acknowledged as shaping patterns and processes of international migration, surprisingly little effort has gone into theorising the collective activities of these actors in commercialising the migration system. Building on the initial ideas of Harney (1977) and Salt and Stein (1997), the range of profit-orientated actors that are involved in facilitating mobility for commercial gain is increasingly being termed the migration 'industry'. Castles and Miller (2003), while doing little work on the topic themselves, coined the term, describing diverse actors such as international recruitment organisations, lawyers, agents, smugglers and other intermediaries as a migration industry. This operates as a 'meso-structure' between the micro and macro structures, as outlined earlier in the work of Findlay (1990) in terms of a migration channels framework. Initially the term 'migration industry' was used only sporadically as shorthand for the mixture of individuals and organisations that profit from facilitating migration. As a consequence it lacked theoretical 
depth and was critiqued for lacking coherence as an analytical contribution (Hernandez-Leon, 2005).

Whilst still a comparatively novel and evolving concept, research on migration industries can be loosely characterised as either focusing on how actors in relatively wealthy countries derive profit from reinforcing borders or on how individuals and organisations in less wealthy countries try and subvert them for commercial gain. The research discussed in this article is interpreted through the lens of segmented labour market theory and seeks to offer an alternative interpretation of migration industries. Recognising that segmented western labour markets have an inherent structural demand for migrant labour (McCollum and Findlay, 2015; Anderson and Ruhs, 2010; Friberg, 2012; Piore, 1979), the analysis explores the role of labour providers in 'oiling the wheels' of these processes. Earlier work mapped the role of recruitment agencies in structuring East-Central European migration to the UK. This scholarship illustrated, first, how and why recruitment agencies recruited from this labour source (Findlay and McCollum, 2013; Jones, 2014), second, how these actors embedded themselves within transnational connections (Sporton, 2013) and third, how these processes produced an increasingly globalised labour force (McDowell et al, 2008). However the workings of these intermediaries have rarely been explicitly considered within a migration industry analytical framework. Positioning these quantitatively significant actors as central to conceptualisations of the migration industry is the main theoretical contribution offered by this analysis.

An interesting exception to most research on the migration industry is Garapich's (2008) use of this concept to illustrate how profit driven institutions have sought to stimulate recent Polish migration to Britain. His analysis contends that the migration industry has been especially responsive to the needs of migrants for information and access to host-society institutions. Thus international recruiters partially replaced traditional agents of civil society in stimulating mobility and easing adaptation. Garapich (2008) calls for an analytical approach that does not view the practices carried out by actors that are driven by market forces as inherently distinct from those undertaken by organisations that are not profit driven, such as voluntary organisations and advocacy networks. This perspective challenges the conceptualization found in the earlier literature which represented market forces as fundamentally opposed to civil society: the so-called 'liberal paradox' whereby political factors were seen as instinctively pro- 
migration control whereas market forces were presumed to be inherently pro-open borders (Hollifield, 2004).

Taking inspiration from Garapich's (2008) deconstruction of the conventional analytical divisions between a) the state as the principle regulator responsible for migration control, b) labour providers as agents driven by primarily by profit and c) migrant social networks as altruistic stakeholders, this approach encourages interrogation of the ways in which recruiter's link to other key actors in the migration system. In turn it recognizes how their actions can 'blur the lines' between the roles served by organisations within the migration industry. Garapich's (2008) approach, and the perspective taken in this research, represents a positive response to Sorensen and Gammeltoft-Hansen's (2013) plea for research that links the migration industry to the outcomes observed in the wider migration system, as opposed to conventional perspectives which have tended to look at specific types of actors in isolation.

In addition to questioning the core definitions and analytical boundaries of the migration industries concept, the research reported in this paper seeks to make a number of other theoretical contributions. Much of the research literature relating to the migration industry views migration through the lens of the aspirations, experiences and outcomes of migrants, and/or the intermediaries that are engaged in facilitating their mobility (Sorensen and Gammeltoft-Hansen, 2013). These approaches have tended to privilege individual micro and meso level perspectives over the wider macro structures that ultimately shape the context within which mobility occurs. This analysis is careful to not only pay attention to the perceptions and practices of important actors within the migration system, but also to the broader political and economic structures that shape these processes. In particular the investigation highlights the dynamism and resilience of migration industries in response to external challenges.

Related to this, there is a need for scholarship on the migration industries to focus on the nature of the connections between the various actors that constitute the migration system. In this paper we examine the perceptions and practices of labour providers, not in isolation, but in terms of their functions as intermediaries connecting the so-called 'demand' and 'supply' sides of the 
labour market at specific points in time and space. This entails consideration of how recruiters engage with both employers and migrants in the pursuit of profit, demonstrating the mutual dependencies that exist between providers and users of migrant labour as well as the strategies used by labour providers to recruit through migrant social networks. Finally, the analysis deepens understanding of the migration industries by illustrating how the act of facilitating migration is only one of many ways through which labour providers are able to generate commercial gain from acting as labour market intermediaries in the migration system.

Based on these approaches, the following overarching research objective has been formulated:

What strategies do labour providers develop to extract financial gain from their interactions with employers and migrant workers, and how do the practices that flow from these strategies help deepen understandings of the migration industry?

\section{Methodological perspective}

Research on labour providers in migration studies, including within the migration industries paradigm, often focuses on migrants and their motives and experiences of using labour market intermediaries and the outcomes of these processes for individual movers (Lindquist, 2010). The focus of research on this paper, by contrast, emphasises the important role that employers play in not only creating a (structural) demand for migrant labour but also sustaining the migration industry itself through the use of recruitment agencies to connect with this source of labour. Conceptually this shifts attention from the individual migrant towards the wider economic and political structures that shape the migration industry.

The analysis draws on in-depth interviews with providers (recruitment agencies) and users (employers) of migrant labour. The interviews were carried out across four UK case study sites as part of a larger research programme (2010-12) investigating the demographic impacts on the UK of migration from East and Central Europe since 2004 (Travena et al, 2013). The research concentrated on the food production and processing and hospitality sectors, which were judged to be key parts of the labour market associated with East-Central European workers (McCollum, 2013). The case study sites included rural and urban areas of England and Scotland 
(West Sussex/Hampshire, Southampton, Angus/Fife and Glasgow). Recruiters were questioned on their experiences and strategies with regards to engaging with employers (clients) and migrant workers (candidates). Employers were asked about their motivations for and experiences of using recruitment agencies to source migrant labour. The logic behind these methodological choices was to examine the factors that create and sustain the demand for a migration industry to service the flexible labour market from the perspective of recruiters and their 'clients'.

East-Central European migration to the UK since the 2004 A8 accession to the EU is an appropriate empirical lens for a study of the migration industry for a number of reasons. First is that it has been remarkable due to the sheer volume of arrivals over a relatively short space of time and the geographically dispersed pattern of immigration (Burrell, 2009). From a labour market perspective, the existing body of research has pointed to employers having positive perceptions of East-Central Europeans (Scott, 2013a) and of these workers disproportionately occupying low paid and temporary forms of employment (Migration Advisory Committee, 2014). East-Central European workers are often portrayed by employers as having a superior 'work ethic' to local workers (MacKenzie and Forde, 2009). This represents a form of direct and indirect discrimination in recruitment practices whereby employers recruit based on national stereotyping, with the suitability of workers for particular roles being determined categorically rather than on individual merit (Lucas and Mansfield, 2010). This leads to ethnically ordered hiring queues whereby employers devise an implicit hierarchy of nationalities according to their desirability as employees (Scott, 2013a). These processes may be thought of as a form of cumulative causation whereby the ample supply of flexible migrant labour, and high employer demand for it, become mutually reinforcing and institutionalised over time (Ciupijus, 2011). Existing research has identified the strategies used by low-wage employers to specifically target A8 migrants in their recruitment processes. These tactics include: direct recruitment from East-Central Europe, recruitment through migrant social networks and the use of recruitment agencies associated with A8 migrant labour (McCollum et al, 2013; Findlay and McCollum, 2013). In turn migrant workers have been shown to respond to employer expectations by 'performing' in ways which meet the stereotypes associated with their ethnicity or region of origin (Waldinger and Lichter, 2003). 
Labour providers have been recognised as a key driver of the significant migration of EastCentral European migrant labour into the UK labour market since 2004 (Sporton, 2013; Garapich, 2008). Accurate data on the means through which migrants find employment are scarce, but it can be reasonably assumed that around half of new arrivals from the Accession 8 countries (Poland, Czech Republic, Latvia, Lithuania, Slovakia, Slovenia, Hungary and Estonia) over the period 2004-2011 initially found work in the UK through recruitment agencies (McCollum, 2013). The research involved 61 in-depth interviews. The labour providers interviewed all had at least one site in the case study areas and ranged from individuals who ran their own recruitment businesses to large nationwide and multinational recruitment agencies. The position held by most of the interviewees was overall director of the firm, or local/regional managers in the case of larger organisations. The labour users who were interviewed ranged from large multinational organisations to smaller employers. Most of the hospitality employers were hotel or restaurant chains and most interviewees were general or personnel managers. The food production and processing interviews focused on farms and vegetable and meat processing companies. Most of the interviewees held the job title of operations or human resource managers within their firm. Overall 26 per cent of the organisations that were contacted agreed to take part in the research. Only 12 per cent explicitly refused to participate in the study, the remaining 62 per cent could not be contacted in a follow up round of telephone calls. Pseudonyms have been used in the quotations which follow to protect respondents' anonymity.

\section{The migration industry's strategies to serve the labour 'needs' of the low wage economy}

A criticism of the research literature on the migration industry is that there has been too little investigation of how the industry structures migration through the commercial interactions between labour providers and employers. In this section we identify a) the practices that labour providers perceive to be central to making them attractive to employers and $b$ ) the importance given by recruitment firms to their relationships with employers. In the next section we present evidence of how labour providers adapt to the restructuring of migration flows as a result of changing economic circumstances by sourcing migrants in different ways. 
The recruitment industry is often thought of simplistically as actors seeking to derive profit from the process of matching employers 'seeking labour' with workers 'seeking work'. Early research represented recruiters as filters in the selection of workers to be channelled to given migration destinations (Findlay, 1990). Later research (Rogaly, 2008) revealed how in relation to low wage labour much of the value extracted from migrants comes from the regulation of the workplace and the terms of employment. In this context, intermediaries such as international labour providers accrue surplus from organising the commodity (labour) so that it is provided in an appropriately packaged fashion that is attractive to the employer. In the context of recent East-Central European migration to the UK, labour providers have taken particular advantage of sitting at the nexus between flexible migrant labour and flexible labour market structures (McCollum and Findlay, 2015). In what follows we focus on those activities that reveal how value is extracted by labour providers. In particular, the way recruiters elect to engage with potential pools of migrant labour is crucial to their 'business interests' since their commercial success rests on the perennial provision of a supply of 'good' workers to employers. Furthermore, recruiters must simultaneously foster and maintain positive relationships with 'clients' (employers) in order to sustain a market for their 'product' (migrant labour).

(a) Labour provider services to employers. It is perhaps not surprising that recruitment agencies flourish in low wage sectors since it is in this context that they are able to offer employers the greatest 'flexibility' in terms of how they use labour (McCollum and Findlay, 2015; Sporton, 2013). A major attraction is the ability of recruitment agencies to provide employers with a 'secondary' workforce to 'top up' their core staff. This is especially attractive in instances where employers are faced with frequent fluctuations in demand for their goods and services and thus demand for labour. The role of recruiters in this process is in facilitating the operation of segmented labour markets (Piore, 1979; Waldinger and Lichter, 2003), whereby particular functions become associated with specific pools of labour, in this case recent East-Central European migrants as a contingent labour force. Norma (an HR officer) offers us insight into how many of the firms we interviewed reported their perceptions of the role of recruitment agents: 
'We don't even know what production is going to be like next week because we are so dependent on the weather and customer orders so the number of people we need changes constantly. So we have about 500 permanent people and we use an agency to top-up our numbers whenever we need them during the high production spells... we contact the agency and they get the people in at very short notice and then they take them away again when production slows and that's better for us than hiring then making people redundant all the time'.

Norma, HR officer, food processing plant, rural England

Norma's coding of the value of recruitment agencies for a low wage employer is that they 'get' and 'take away' labour, an employment service that is of value because it avoids the 'costs' of 'redundancy' in an uncertain labour market. Labour providers are presented as enablers providing labour as a commodity in a fashion akin to a tap which can be turned on and off easily and frequently.

Another key attraction of labour providers for employers was that they operated as a 'one stop shop' for staff recruitment and management, allowing effective outsourcing of human resources functions. Barry, a labour provider describes his self-perception of how recruiters provide a valuable role to low wage employers by sourcing flexible labour, whilst simultaneously relieving them of the legal responsibilities associated with recruiting and employing staff directly themselves.

'Using someone like us gives them flexibility...they might not have the facilities or be able to manage the hassle of taking staff on themselves because then they've got to go out and buy them work wear and put them through health and safety training and they have got to do the interviewing for them. Whereas with us it is just one stop, we will give you that man and we'll pay them what we want and that is it, so there is no hassle'.

Barry, managing director, labour provider firm, urban Scotland

(b) Labour provider relations with employers. The examples above illustrate two ways in which recruitment agencies facilitate the operation of the flexible labour market. Whilst this has already been the focus of empirical research (Anderson and Ruhs, 2010; Scott, 2013b), much less is known about how recruiters establish and cultivate relationships with employers in order to try and extract profit from the provision of a flexible workforce. This focus builds on Sorenson and Gammeltoft-Hansen's (2013) call for research into the actual linkages between the migration industry and other actors in the migration system. It is already well established that employers rely on the migration 
industry to help them engage with flexible (migrant) labour (Jones, 2014), meaning that the recruitment industry and low-wage employers are often mutually dependent on each other for commercial success within the highly competitive marketplaces that they each operate within.

I mean it is absolutely cut throat in this industry, even with the farm market there are so many agencies getting into it now that you're finding that it is more difficult to survive... and guys [employers] are seeing how I'm working and then getting the people [workers] themselves, or are going through my agencies in Eastern Europe directly, so I'm gradually getting pushed out of the picture'.

Ethan, managing director, labour provider firm, rural Scotland

In the context of such a competitive industry, recruiters often emphasised the strategic importance of cultivating a positive business reputation and fostering strong interpersonal relationships to attracting and retaining clients.

'We deal with a number of key clients, supporting them with flexible staff and permanent solutions so in essence we can be a one stop shop for them... but there is a perception that clients can just turn the tap on and off again when they want: they think we've got people stacked up in a cupboard that we just open the door and they fall out. But that is not what happens and this is where we work closely with clients and trust is key so I am fully transparent with clients. I show them the pay rate, the holiday pay, national insurance, our profit, and the total charge rate. To have that long-term sustainable relationship you have to be open'.

Ben, senior partner, labour provider firm, urban Scotland

As the quotation from Ben suggests, interviewees noted the importance of positive relationships with employers to the sustainability of profitable longer term business dealings with them. This analytical emphasis on the functions served by recruiters in providing employers with a flexible labour supply, and the strategies used by them to develop relationships with clients has implications for understandings of migration industries in the context of a legislative environment whereby a large part of the function of labour market intermediaries does not involve subverting or negotiating the crossing of borders, but rather they involve providing a particular 'employment regime'. The actions of recruiters in this context are orientated towards offering services to employers that enable them to make use of flexible migrant labour, whether it be directly sourced from abroad or already in the host country. In this sense the role of labour providers in the migration industry is only partially about helping workers find employment overseas. Other commonplace recruitment and employment services offered by labour providers include language translation, staff training 
and onsite HR management (Findlay and McCollum, 2013). Equally important to their commercial viability is developing and maintaining business relationships with the users of migrant labour. This distinction is important because the analytic focus on labour providers in migration research is often mostly or exclusively on how they help migrants move to and find employment in another country.

As discussed by Janine, the success or otherwise of recruiters is dependent upon their ability to satisfy both their clients and their candidates simultaneously. This intermediary role represents a significant challenge given that the aims of each group are mutually opposing: employers wish to extract as much value as possible from labour, whereas the aim of workers is to maximise the returns on their labour.

'For us it is not all about money and I think that comes across to our clients and we tend to retain our clients and I think that is because I regularly contact them and our account manager contacts them. The branch manager contacts them too. But as well as the client-facing part of my role I also try and find out how the candidates are experiencing our service. It is good to hear the story from both the client and the candidates' perspectives because it is 50/50: you can't do the job properly if you just service one side of that equation'.

Janine, labour provider, urban England

\section{Changing approaches to sourcing migrant workers}

The attraction to employers of using migration industry intermediaries to source cheap flexible labour while at the same time outsourcing their legal obligations to migrant workers by asking the migration industry to provide this service is now evidenced by an increasing body of research (McDowell et al, 2008; Sporton, 2013; Findlay et al, 2013; Pemberton and Stevens, 2010; Jones, 2014). What is less apparent and has been the subject of only a small number of studies is the strategy adopted by recruitment agencies to meet employers' expectations of constantly being able to supply flexible workers at short notice (discussed above by Norma). It is accepted that migrants' 'dual frame of reference' makes them tolerant of relatively poor employment conditions (Piore, 1979). This could potentially explain the ability of recruiters to perpetually source and supply flexible migrant workers. However such an explanation fails to account for how migrants' willingness to accept unfavourable employment conditions erodes over time as they become attuned to norms surrounding earning expectations in their host 
society. This phenomenon was brought up by many interviewees, who bemoaned a perceived erosion of the 'work-ethic' of migrants with time spent in Britain.

'Their standards are starting to drop off now and they are beginning to go native a bit and display a lot of the characteristics of our own [UK] workforce... unfortunately they are adapting some of our cultures in terms of attitude to work'.

Jack, food processing firm, rural Scotland

The migration industry has once again seen this eroding 'work culture' effect as an opportunity to extend their services to employers through undermining the position of more established migrant workers. The quotation from Iris (below) shows how this operates through what neoMarxian researchers would see as the periodic tapping of new reserve armies of labour. This interpretation is of interest as it theorises the expansion of potential pools of migrant labour as a novel spatial fix to the perennial problem of crises of over-accumulation within the capitalist system (Anderson and Shuttleworth, 2004). The role of the enlargement of the EU eastwards in facilitating the control of capital over labour is an issue that merits much more attention than it has received to date.

'It is a cycle, the A8 countries joined the EU in 2004 and now we are a good few years into the process, so the honeymoon period is sort of over. So I always think: when are we going to have new countries coming in [to the EU], because we will always need them because you have those five to ten year periods where people are happy to do anything but as their economies pick up they will be gone and if they are not gone then they want better jobs. So it needs to be a cycle and we need to always bring new countries on board'.

Iris, manager, labour provider firm, urban England

In terms of labour supply, recruiters can be thought of as facing two significant challenges with respect to the business of migration. As discussed by Iris, the first is the ability to source and have 'on tap' a ready new supply of migrant workers who are tolerant of poor pay and employment conditions. This is difficult because migrant workers often become less accepting of undesirable jobs as the time spent in their host country increases. A second challenge faced by recruiters is that the extent to which employers and migrants rely on labour market intermediaries decreases as a migration system evolves (Hernandez-Leon, 2013). In the case of East-Central European migration to the UK, the field research confirmed that the use of labour providers diminished somewhat over time as migrant social networks came to play a bigger role in the recruitment practices of employers. For employers this approach had the attraction of subverting the charges made by recruitment agencies through enrolling their own 
migrant staff as recruiters of 'good workers', thus getting them to exercise social power over newly recruited staff. The discourse encouraged by employers is therefore that 'good' workers are likely to recommend other 'good' workers (McCollum and Apsite-Berina, 2015). The field research revealed the strategies that labour providers use to manage these challenges in relation to their goals of recruiting and retaining a large flexible workforce supplied to employers at short notice.

\section{Challenge A: the perennial supply of 'good workers'}

Many labour providers noted that their ability to meet the demands of employers for cheap labour was contingent upon external political and economic circumstances making it possible to source 'fresh' supplies of migrant labour. Interviewees alluded to three distinct phases between the accession of new countries to the EU in 2004 and the global recession that was to follow a few years later. The period following the 2004 accession represented a boom for the UK migration industry: employers were keen to engage with migrant labour but were unsure of how to go about doing so, and the novel nature of the new migration stream meant that migrants needed labour market intermediaries to help them move and find work in the UK.

'If you went back to 2007 you'd find about 90 per cent of all the Eastern Europeans were in temporary jobs through agencies. And in the early days we did a lot of interviewing in the countries and brought people over and we set them up with banks, doctors, dentists and we even actually rented flats and sub-leased them to the EU folks and we had an existing group of English speaking Czechs and Hungarians employees who really integrated them'.

Wallace, managing director, labour provider firm, urban Scotland

The migration industry faced a number of challenges in the second phase, the period immediately preceding the recession. It became harder to recruit directly from East-Central Europe as the labour markets of these countries improved and the booming British labour market meant that migrants already in the UK were aiming for and achieving 'better' jobs than those offered by employers in low wage sectors. 
'Certainly 2007 and 2008 were awful years for making sure farms got enough people. You could have people earning $£ 500$ a week and they weren't happy. We had people walking into our recruitment offices in Latvia and saying I want a job at $£ 12$ an hour. And farms weren't happy because they didn't have enough people so a lot of fruit was left in the fields... that was good in one way because it made farms wake up to the fact that Eastern Europe is not a bottomless pit of labour. That you can't just send a bus to Warsaw and fill it up with strawberry pickers'.

Josh, regional manager, labour provider firm, rural England

The onset of the recession (the third phase) was described as something of a 'blessing in disguise' for the migration industry. It generated a resurgence in demand for their services from a new wave of 'crisis' migrants from Eastern and Central Europe, who were accepting of poor pay and conditions owing to the severity of the recession in their home countries. Migrants that were already in the UK were forced to turn to recruiters to seek employment opportunities and had lowered demands regarding pay and employment conditions.

'At the moment we don't need to do much searching for candidates, but before the recession the job was more about candidates than it was clients because the clients were desperate and candidates were all in work so you really had to search. Whereas now the clients aren't desperate and the candidates are so it has just switched the other way. But yeah the migrants have made a difference because they've come here to work, and the benefits just keep the local guys at home and stops them wanting to work'

Richard, recruitment consultant, labour provider firm, rural Scotland

The three phases discussed above underline the shifting and sometimes insecure business environment within which individual actors in the migration industries operate. This dynamism relates not only to the influence of labour market metrics such as wage levels, but also to the role of perceptions and social practices of all actors involved in the process. This includes national and supra-national scale policies, employers and transnational communities both in the source and sending countries.

\section{Challenge B: migrant social networks}

A second challenge faced by labour providers is that recruitment through informal migrant networks have become an increasingly popular channel through which low wage employers source labour. Such an approach was interpreted as enabling the recruitment of 'good' workers, whilst exerting little or no financial cost on employers. Firms encouraged recommendations from 'good' staff members of potential future employees with appropriate traits and abilities. 
This application of the 'homophily principle' (Lin, 1999), which refers to members of a network sharing similar attributes, implies that networks of 'good workers' can reproduce and maintain a 'good' workforce through further migrant recruitment (McCollum and ApsiteBerina, 2015). Aiden illustrates the principle in action;

'I actually set up a scheme where if somebody recommended a person to come and work with us and that person then stayed with us then I would give them £100. And that was a strategy that worked because that way there was more pressure to make sure that the people that they were recommending were good and going to last. So that works really well. If they are prepared to vouch for somebody then I am prepared to give them a go. So there is absolutely no need for paying any agencies because it is all done through word of mouth'

Aiden, manager, restaurant, urban Scotland

Recognising the futility of trying to compete with migrant social networks, one response of recruiters was to embed themselves within transnational networks and exploit them as potential suppliers of 'good' workers to the migration industry. These tactics often involve recruitment agencies employing migrants, usually former candidates, as consultants in order to use their networks to tap into potential pools of labour.

'Word of mouth in the Eastern European communities is very important so they always share information about jobs and that is great for us because my guys [consultants] are all Eastern European so they have got their own networks too. So all the advertising for people is done predominantly through them and their word of mouth. So they can pick up the phone and get 20 people instantly because they have their own contacts and know so many people'.

Samantha, director, labour provider, rural England

The emphasis placed on enlisting migrants as recruitment agents in order to tap into their networks leads to a blurring of the conceptual lines between the migration industry and migrant social networks. The former is usually thought of as comprising those whose primary motivation in facilitating migration is commercial gain, whereas the motivations of the latter are conventionally thought of as being altruistic. Instead what seems to occur in this instance is a combination of both of these drivers: recruiters 'helping' their co-ethnics find jobs, but also contributing to the commercial success of organisations in the migration industry through these practices. The lesson from these findings is that the components of the migration industry, as defined purely by the profit motive, are analytically difficult to separate from the myriad of other individuals and organisations that are engaged in facilitating migration. Just as migration is multi causal, the drivers behind the practices that motivate individuals to enable it are also complex and overlapping. As such it would be inadvisable for researchers to try and set overly 
strict and mutually exclusive analytical categories and boundaries between the various actors that facilitate mobility in the migration system (Garapich, 2008). The implications of these issues for conceptualisations of the migration industry are considered in the concluding section.

\section{Conclusions}

A longstanding feature of international migration is the use by migrants of intermediaries to help cross international borders and find employment in another country. This investigation has focused on the internal workings of a quantitatively significant type of migration intermediary: recruitment agencies engaged in matching low-wage employers seeking 'flexible' workers with recent East-Central European labour migrants seeking employment in the UK. It is hoped that this perspective contributes to the emerging literature on the migration industries, a concept that has been loosely and sporadically applied to the various individuals and organisations that seek to derive profit from the process of facilitating migration (Sorensen and Gammeltoft-Hansen, 2013). In particular the analysis sought to offer useful insights into the strategies used by recruiters to engage with and sustain business links with employers, and the tactics used in the supply of a valued product: 'flexible' workers. This perspective is useful since positive relationships with clients (employers) and candidates (migrants) are both essential if recruiters are to successfully derive financial gain from the business of international migration. As opposed to the conventional focus on migrants and their motives for and experiences of using labour providers, this analysis has explored the migration industry from the perspective of the relationships and interactions between recruiters and the employers that utilise them to engage with migrant labour.

In terms of the focus of this special issue on theorising the migration industry, the research has shed some light on the 'black box' between migrants wishing to engage in mobility and the outcomes of these moves (Lindquist et al, 2012). Whilst wary of concurring with the notion of a 'gaping theoretical hole concerning the position, contribution and relations of profit-driven actors in the social organisation of international migration' (Hernandez-Leon, 2013, 24), the authors share Garapich's (2008) interest in extending understanding of the ways in which recruiters link with other key actors in the migration system, and how these actions can 'blur the lines' between the roles served by individuals and organisations within the migration 
industry. Such a stance represents a positive response to Sorensen and Gammeltoft-Hansen's (2013) call for research that links together various components of the migration industry and migration system, as opposed to perspectives that look at specific types of actors within it in isolation.

Using the empirical lens of recent East-Central European migration to the UK, the analysis emphasised how the strategies used by recruiters to engage with and satisfy both employers and migrant workers is essential to their ultimate goal of deriving commercial gain from migration. However this also illustrates the difficulty, and perhaps futility, of trying to define the migration industry as a strictly separate analytical category in migration studies. Much of the existing literature relating to this concept focuses on how profit driven actors seek commercial gain from facilitating or controlling migration, when engaged by migrants and governments respectively. However this analysis indicates that enabling the act of migration is often only a minor part of the business activities of labour providers, actors who would be thought of as constituting a major cog in the migration industry. Theorisation of the migration industry therefore needs to go beyond just conceptualisation of how actors motivated by profit facilitate migration. These perspectives also need to focus on the other core activities of these actors and the aggregate effect of these actions on migration systems more generally.

Just as the strategies of labour providers extend beyond the facilitation of the act of migration, thus loosening the definition of the migration industry, the research also problematizes some of the analytical categories within this conceptual framework. As with Garapich (2008), the findings question the analytical distinctions in the migration system between recruiters as driven by profit, and migrant social networks, whose actions are usually portrayed as being more altruistic. In the case of the recruitment of migrants by labour providers, strategies have developed which represent a combination of both of these drivers: recruitment consultants 'helping' individuals within their social networks gain employment opportunities, whilst also contributing to the commercial success of organisations in the migration industry through these practices. The lesson from these findings for understandings of the migration industry is that scholars need to pay careful attention to the links and analytical boundaries between the actors involved in the business of migration and the range of other individuals and actors that are involved in facilitating mobility. 
Furthermore, the framing of the migration industry as a 'meso-structure' in migration systems, emphasises the significance of profit-motivated actors in shaping patterns and processes of international migration. It also highlights the resilience but also limited agency of the individual components of this industry. As discussed above, the recruitment agency sector is highly competitive and both clients (employers) and candidates (migrants) can have alternative means of connecting with each other beyond this 'industry'. As illustrated by the findings showing the shifting prominence of labour providers in structuring recent East-Central European migration to the UK, the positioning of these profit driven actors in the migration system (and thus of the migration industry itself) is contingent upon favourable external political and economic circumstances.

To conclude, this investigation has contributed to an already established body of evidence in relation to labour providers, East-Central European migrant labour and flexible labour market structures (McCollum and Findlay, 2015; Sporton, 2013; Jones, 2014). But how does the concept of the migration industry fit into these understandings? The migration industry framework has only been applied in a loose and sporadic fashion by migration scholars and as such has lacked coherence as a longer term analytical concept (Hernandez-Leon, 2005). As such it has thus far made only a limited contribution to deepening understandings of migration. A challenge in this respect is the wide breadth of the stated defining features of the migration industry: the profit motive and the facilitation of migration. This research has highlighted complications with both aspects of this classification criteria. Of those who profit from being engaged in facilitating migration, and who are therefore a component of the migration industry, the actual process of promoting mobility can constitute only a minor part of their operations, as is the case with many of the labour providers interviewed as part of this research. Similarly, commercial gain is only one of many motivating factors amongst some of those who fall into the migration industry category, such as migrants working as recruitment consultants whilst assisting those within their social networks to find employment opportunities. Moving forward, greater attention to the links and analytical boundaries between profit motivated individuals and organisations and other actors in the migration system, and the macro structural spatiotemporal context within which these relations play out, can help to advance this approach as a cohesive theoretical framework in migration studies. 


\section{Acknowledgment}

This research was conducted by researchers in the Centre for Population Centre, funded by the Economic and Social Research Council (ESRC) grant number RES-625-28-0001.

\section{References}

Anderson, B. and Ruhs, M. (2010). 'Migrant Workers: who needs them?' . In M. Ruhs and B. Anderson (eds) Who Needs Migrant Workers? Oxford University Press. Oxford. pp 15-52.

Anderson, J. and Shuttleworth, I. (2004). 'Theorising State Borders in Capitalism: Spatial Fixes Old and New'. Centre for International Borders Research. Electronic Working Papers Series. Queens University Belfast.

Bilger, V. Hofmann, M. and Jandl, M. (2006). 'Human Smuggling as a Transnational Service Industry: Evidence from Austria'. International Migration 44(4). pp 59-83.

Brettell, C. and Hollifield, J. (eds) (2015). Migration Theory, talking across disciplines. Third edition. Routledge. London.

Burrell, K. (2009). 'Introduction'. In K Burrell (ed) Polish Migration to the UK in the 'New' European Union. Ashgate. Farnham. pp 1-22.

Castles, S. de Haas, H. and Miller, M. (2013). The Age of Migration. Fifth Edition. Macmillan. Basingstoke.

Castles, S. and Miller, M. (2003). The Age of Migration. Third Edition. The Guilford Press. New York.

Ciupijus, Z. (2011). 'Mobile central eastern Europeans in Britain'. Work, Employment and Society 25(3). pp 540-550.

Coe, N. Jones, J. and Ward, K. (2010). 'The Business of Temporary Staffing: A Developing Research Agenda'. Geography Compass 4(8). pp 1055-1068.

Cranston, S. (2016). 'Producing Migrant encounter: Learning to be a British Expatriate in Singapore through the Global Mobility Industry'. Environment and Planning D: Society and Space. Early view version. 
Findlay, A. (1990). 'A Migration Channels approach to the Study of high level Manpower Movements: a Theoretical Perspective'. International Migration 28(1). pp 15-24

Findlay, A. and Li, F. (1998). 'A Migration Channels Approach to the Study of Professionals moving to and from Hong Kong'. International Migration Review 32 (3). pp 682-703.

Findlay, A. and McCollum, D. (2013). 'Who is recruited and how? Migrant Labour Channels in the Agribusiness Sector, from Accession to Recession'. Journal of Rural Studies 30. pp 1019

Findlay, A. McCollum, D. Shubin, S. Apsite, E. and Krisjane, Z. (2013). 'The Role of Recruitment Agencies in Imagining and Producing the 'Good' Migrant'. Social and Cultural Geography. 14(3). pp 145-163.

Friberg, J. (2012). 'The Stages of Migration. From going Abroad to Settling down: postAccession Polish Migrant Workers in Norway'. Journal of Ethnic and Migration Studies 30(10). pp 1589-1605.

Friebel, G. and Gurlev, S. (2006). 'Smuggling Humans: a Theory of Debt-financed Migration'. Journal of the European Economic Association 4(6). pp 1085-1111.

Garapich, M. (2008). 'The Migration Industry and Civil Society: Polish Immigrants in the United Kingdom Before and After EU Enlargement'. Journal of Ethnic and Migration Studies 34(5). pp 735-752.

Harney, R. F. (1977). 'The Commerce of Migration'. Canadian Ethnic Studies/Etudes Ethniques du Canada 9. pp 42-53.

Hedberg, C. Hermelin, B. and Westermark, K. (2014). 'Transnational Spaces 'From Above' - The Role of Institutions in Promoting Highly Skilled Labour Migration from India to Sweden'. Tijdschrift voor economische en sociale geografie, 105(5). pp 511-525

Hennebry, J. (2008). 'Bienvenidos a Canadá? Globalization and the Migration Industry Surrounding Temporary Agricultural Migration in Canada'. Canadian Studies in Population 35(2). pp. 339-356

Hernández-León, R. (2005). 'The Migration Industry in the Mexico-U.S. Migratory System'. Los Angeles: UCLA, California Center of Population Research Online Working Paper Series 049-05. 
Hernandez-Leon, R. (2008). The Migration of Urban Mexicans to the United States. University of California Press. Jackson, TN.

Hernandez-Leon, R. (2013). 'Conceptualising the Migration Industry'. In T. GammeltoftHansen and $\mathrm{N}$ Sorenson (eds) The Migration Industry and the Commercialisation of International Migration. Routledge. London. pp 24-44.

Jones, K. (2014). 'It Was a Whirlwind. A Lot of People Made a Lot of Money'. Central and Eastern European Migration Review 3(2). pp. 105-125.

Koser, K. (2011). 'Why take the risk? Explaining Migrant Smuggling'. In T. Modood and J. Salt (eds) Global Migration, Ethnicity and Britishness. Palgrave Macmillan: Basingstoke. pp 65-83.

Kyle, D. and Koslowski, R. (eds). (2001). Global Human Smuggling: Comparative Perspectives. Johns Hopkins University Press. Baltimore, MD.

Lin, N. (1999). 'Social Networks and Status Attainment'. Annual Review of Sociology 25. pp 467-487.

Lindquist, J. (2010). 'Labour Recruitment, Circuits of Capital and Gendered Mobility: Reconceptualising the Indonesian Migration Industry'. Pacific Affairs 83(1). pp 115-132.

Lindquist, J. Xiang, B. and Yeoh, B. (2012). 'Introduction: Opening the Black Box of Migration'. Asia Pacific Affairs 85(1). pp 7-18.

Lucas, R. and Mansfield, S. (2010). 'The use of Migrant Labour in the Hospitality Sector: current and future implications'. In M Ruhs and B Anderson (eds) Who Needs Migrant Workers? Oxford University Press. Oxford. pp 159-186.

MacKenzie, R. and Forde, C. (2009). 'The Rhetoric of the 'Good Worker' versus the Realities of Employers' Use and the Experiences of Migrant Workers'. Work, Employment and Society 23(1). pp 142-59.

McCollum, D. (2013). 'Investigating A8 Migration using Data from the Worker Registration Scheme: temporal, spatial and sectoral trends'. Local Economy 28(1). pp 35-50. 
McCollum, D. and Apsite-Berina, E (2015). 'Recruitment through migrant social networks from Latvia to the United Kingdom: Motivations, Processes and Developments'. Migration Letters 12(1). pp 50-66.

McCollum, D. and Findlay, A. (2015). 'Flexible' Workers for 'flexible' jobs?' Work, Employment and Society 29(3). pp 427-443.

McCollum, D. Shubin, S. Apsite, E. and Krisjane, Z. (2013). 'Rethinking Labour Migration Channels: the Experience of Latvia from EU Accession to Economic Recession'. Population, Space and Place 19(6). pp 688-702.

McDowell, L. Batnitzky, A. and Dyer, S. (2008). 'Internationalization and the Spaces of Temporary Labour: The Global Assembly of a Local Workforce'. British Journal of Industrial Relations 46(4). pp. 750-770.

Migration Advisory Committee. (2014). 'Migrants in Low-Skilled Work'. MAC. London.

Pemberton, S. and Stevens, C. (2010). 'The Recruitment and Retention of Central and Eastern European Migrant Workers in the United Kingdom: A Panacea or a Problem under the New Policies of ‘Managed Migration'?’ Regional Studies 44(9). pp 1289-1300.

Piore, M.J. (1979). Birds of Passage. Cambridge University Press. Cambridge.

Rogaly, B. (2008). 'Intensification of Workplace Regimes in British Horticulture'. Population Space and Place 14(6). pp 497-510.

Salt, J. and Stein, J. (1997). 'Migration as a Business: the Case of Trafficking'. International Migration 35(4). pp 467-494.

Salt, J. and Wood, P. (2011). 'Acquisition and Mobility of Expertise in Global Corporate Labour Markets'. In T. Modood and J. Salt (eds) Global Migration, Ethnicity and Britishness. Palgrave Macmillan: Basingstoke. pp 84-107.

Scott, S. (2013a). 'Migrant-Local Hiring Queues in the UK food industry'. Population, Space and Place 19(5). pp 459-471.

Scott, S. (2013b). 'Migration and the Employer Perspective'. Population Space and Place 19(6). pp 703-713. 
Sorensen, N. and Gammeltoft-Hansen, T. (2013). 'Introduction'. In T. Gammeltoft-Hansen and N Sorenson (eds) The Migration Industry and the Commercialisation of International Migration. Routledge. London. pp 1-23.

Soysal, Y. (1994). Limits of Citizenship. University of Chicago Press. Chicago.

Sporton, D. (2013). 'They Control My Life': the Role of Local Recruitment Agencies in East European Migration to the UK'. Population, Space and Place 19(5). pp 443-458.

Travena, P. McGhee, D. and Heath, S. (2013). Location, Location? Population Space and Place 19(6). pp 671-687.

Van den Broek, D. Harvey, W. and Groutsis, D. (2015). 'Commercial Migration Intermediaries and the Segmentation of Skilled Migrant Employment'. Work, Employment and Society. Online early view.

Waldinger, R. and Lichter, M. (2003). How the Other Half Works: Immigration and the Social Organization of Labour. University of California Press. Berkeley, CA. 